\title{
THE LOCAL DIMENSION IN WATER RESOURCES GOVERNANCE: THE EXPERIENCE OF INTER-MUNICIPAL CONSORTIA AND COMMITTEES ON RIVER BASINS
} A DIMENSÃO LOCAL NA GOVERNANÇA DE RECURSOS HÍDRICOS: A EXPERIÊNCIA DOS CONSÓRCIOS INTERMUNICIPAIS E DE COMITÊS DE BACIAS HIDROGRÁFICAS

\section{Yuri Kasahara 우}

Senior researcher, Oslo Metropolitan University - Oslo, Norway.

\section{Maria do Carmo Sobral (1)}

Full professor, Universidade Federal de Pernambuco (UFPE) Recife (PE), Brazil.

\section{Maiara Gabrielle de Souza Melo 구}

Professor, Instituto Federal de Educação, Ciência e Tecnologia da Paraíba - Cabedelo (PB), Brazil.

\section{Correspondence address:}

Yuri Kasahara - PO Box 4, St Olavs Plass, 0130-Oslo, NorwayE-mail: yurik@oslomet.no

Received on: 02/20/2020 Accepted on: 07/05/2020

\section{ABSTRACT}

Integrated water resources management is advancing in Brazil as decentralized and participatory governance gains more prominence. However, local actions need to be better understood since several public policies are effectively implemented at this level. The present article aims to present the current debate about the local dimension in water resources governance. The paper analyzes empirical cases of water resources management in semi-arid Brazil, based on the performance of inter-municipal consortia and São Francisco's River Basin Committee. Research shows that municipalities do not ignore the need to adopt new management models in response to their known financial and technical limitations. Cases of inter-municipal consortia and river basin committees have proven to be opportunities for greater visibility and action of local participants. Inter-municipal consortia assist in sanitation management, because they increase the access of municipalities to the services provided. On the other hand, dynamics of the river basin committee expanded the possibilities of participation of local actors, allowing the debate and shared decision-making. Nevertheless, identifying factors and strategies for the successful organization of local participation and cooperation in these new governance arrangements is needed.

Keywords: water resources governance; local level; inter-municipal consortia; river basin committees.

\section{RESUMO}

A gestão integrada de recursos hídricos no Brasil tem avançado à medida que se amplia a governança descentralizada e participativa. Contudo, há uma necessidade de melhor entendimento sobre a atuação do nível local, tendo em vista que é nesse nível que diversas políticas públicas são efetivamente implementadas. Nesse sentido, este artigo teve por objetivo apresentar o debate contemporâneo sobre o nível local em relação à governança de recursos hídricos no Brasil semiárido, com base no desempenho de consórcios intermunicipais e do comitê de bacia hidrográfica do rio São Francisco. A pesquisa demonstrou que os municípios não ignoram a necessidade de adotar novos modelos de gestão como resposta às suas conhecidas limitações financeiras e técnicas. Os casos dos consórcios intermunicipais e dos comitês de bacia têm se apresentado como oportunidades para maior visibilidade e atuação dos atores locais. Os consórcios intermunicipais têm auxiliado na gestão do saneamento conforme ampliam o acesso de municípios aos serviços prestados. Já a dinâmica do comitê de bacia hidrográfica tem aumentado as possibilidades de participação de atores que atuam em nível local na mesma arena, possibilitando o debate e a tomada de decisão compartilhada. Porém, evidencia-se uma clara necessidade de identificar fatores e estratégias que possibilitem uma organização bem-sucedida de participação e cooperação de níveis locais nesses novos arranjos de governança.

Palavras-chave: governança de recursos hídricos; nível local; consórcios intermunicipais; comitês de bacias hidrográficas. 


\section{INTRODUCTION}

The last two decades were marked by intense global and institutional changes in regulatory frameworks of water resources (CONCA, 2006). Efforts for the implementation of systems inspired on principles of integrated water resources management (IWRM), both in developed and developing countries, led to the creation of a plethora of new institutions for water resources management (WOODHOUSE; MULLER, 2017). The creation of national and state regulatory agencies, as well as river basin committees, was an important institutional innovation for the governance model adopted in Brazil (ABERS; KECK, 2013).

Academic literature has extensively analyzed the processes of implementation and operation of these new institutions in different international, national, and regional contexts. A quick search on Google Scholar shows, for instance, that 16 academic papers with the term water governance were published in 1999. In 2018, 4,080 individual articles including the term were published, with an annual average of 1,469 publications during this period. As a result of this growth, methodological and conceptual approaches, as well as the levels of analysis used, were diversified.

Despite this diversity, some topics are recurrent. The first is the description and analysis of how water resources governance is organized. How are conflicts resolved and how are interests between countries (in the case of cross-border water resources), between different political-administrative entities of the same country (for instance, between central government and states or between municipalities of the same state), between productive sectors and consumers, and between technical and political bodies coordinated? What system of governance is more inclusive and considers the greatest number of voices? How is the process of consolidation of new instances created to manage water resources? These are some of the questions posed in this first topic. The second recurrent discussion is the prescriptive and normative debate on governance. Whereas the first theme has a more descriptive nature, seeking to understand the workings of governance bodies and actors, this second discussion addresses the characteristics of "good" governance, which objectives it should prioritize, and the best ways to reach these goals.

The interaction between these two - completely intertwined - approaches and the knowledge produced by the analysis of numerous cases have gradually led to a consensus: the importance of the local level for understanding the organization of water resources governance (MANCILLA-GARCÍA et al., 2019; SHARMA-WALLACE; VELARDE; WREFORD, 2018; WHALEY; CLEAVER, 2017). The local level does not have a self-evident meaning. It can involve political-administrative units, such as municipalities, or even smaller areas, like neighborhoods or communities of a municipality. As a space, the local level also has no natural representation since it encompasses a great variety of actors. Municipal administrators, rural producers, companies, and neighborhood associations are examples of local actors. Simultaneously, settings with high population density and urbanization exponentially increase the local complexity level. In other words, the governance of large metropolitan areas is much more elaborate than that of small rural municipalities.

The growing interest in the local dimension results from the fact that the policies formulated in higher political and administrative spheres, such as federal and state governments, are effectively implemented at the local level. Therefore, systematic and detailed analyses of local dynamics are crucial to understanding the reasons for the success or failure of governance models. In Brazil, for instance, although municipalities are not directly responsible for the management of river basins, they oversee water supply, and sewage collection and treatment, in addition to being the main regulators of local land use - with direct impact on existing water resources.

Moreover, Goal 6 of the United Nations 2030 Agenda for Sustainable Development (UN, 2015) defends the need to "Ensure availability and sustainable management of water and sanitation for all", with one of its targets declaring the importance of supporting and strengthening the participation of local communities in improving water and sanitation management. In this perspective, local governance becomes paramount, and its improvement, an urgent demand.

According to Philippi Jr., Sobral and Carvalho (2019), reaching the targets of Goal 6 and having instruments for environmental and water resources planning require the creation of governance structures that will lead the implementation of the 2030 Agenda throughout the national territory at the river basin level. 
In Brazil, different governance arrangements involving the local level can operationalize the IWRM. In this regard, the present paper aims to present and analyze the current debate about the local dimension in water resources governance, based on the characterization developed by Hooghe and Marks (2003), detailed in the following topic. After a literature discussion, the study assesses the performance of inter-municipal consortia in providing sanitation services and of São Francisco
River Basin Committee (Comitê da Bacia Hidrográfica do Rio São Francisco - CBHSF). We chose these examples because they detail how the local level can have a differentiated role in water resources management. In conclusion, municipal performance has some gaps, and these local actors need to be consistently engaged. We also suggest the development of some lines of research on the relation between the local dimension and water resources governance in Brazil.

\section{TYPES OF GOVERNANCE AND THE LOCAL LEVEL}

The multifaceted debate on water resources governance reflects the existing diversity in the broader theoretical debate on governance. Ansell and Torfing (2016) discuss, for instance, the different disciplinary backgrounds of the concept. Therefore, a necessary first step is to define the concept of what governance is. In general, when it comes to public policies, governance can be defined as a set of rules that determines which organizations will manage one or several policies/programs in a specific jurisdiction.

Le Galès (2004) defines governance as the process of coordinating actors, social groups, and institutions to achieve goals defined and discussed collectively. Governance refers to a set of institutions, networks, policies, regulations, standards, and political and social practices, as well as public and private actors, which contribute to the stability of a society and political regime, its orientation, its ability to manage and provide services, and its capacity of ensuring its very legitimacy.

Jacobi and Spínola (2019) declare that the concept of governance focuses on the notion of social power, which measures the relations between the State and civil society as a space to build alliances and cooperation. The authors report that governance can be understood as a strategy that stresses the need for social participation in political-decision processes, decentralization of power, and compilation of many interests, goals, and values for common good.

The binary typology developed by Hooghe and Marks (2003) is quite informative in illustrating these definitions (Table 1). According to these authors, Type I governance is inspired by a traditional federal model, in which clearly established geographical jurisdictions are responsible for a combination of programs and public policies (general-purpose jurisdictions). Brazilian federalism would be a typical example of Type I governance, in which federal government encompasses state administrations, which, in turn, include municipal administrations, with well-defined geographical boundaries. At the same time, these government spheres - despite having exclusive competence in many cases - are responsible for the management of programs related to different areas. Water resources management is just one of the tasks under the control of these jurisdictions.

Table 1 - Types of governance and their main characteristics.

\begin{tabular}{|l|c|c|}
\hline & Type I & Type II \\
\hline Geographical coverage & Defined & Fluid \\
\hline $\begin{array}{l}\text { Criteria for membership } \\
\text { and participation }\end{array}$ & $\begin{array}{c}\text { Clearly defined and compulsory } \\
\text { (e.g., citizenship) }\end{array}$ & Flexible and voluntary \\
\hline Thematic jurisdiction & Multiple & Specific \\
\hline Diversity of interests & High & Low \\
\hline
\end{tabular}

Source: adapted from Hooghe and Marks (2003). 
In contrast to Type I, Type II model is characterized by a thematic focus and a geographical jurisdiction that is more fluid or intersects pre-existing jurisdictions. In the international context, many river basin committees created with the dissemination of IWRM principles are examples of Type II governance. Given that river basins do not usually respect the geographical boundaries of states and municipalities (or countries), governance solely based on state and municipal administrations, typical of Type I model, has clear limitations. The need to coordinate the interests of different actors scattered over various political-administrative jurisdictions is better fulfilled by a new institution. Therefore, river basin committees provide these actors with a specific jurisdiction for coordinating their interests as to the use of water resources.

An important debate about these typologies is the one involving the participation of citizens and organized groups - mainly in democratic societies. In Type I governance, the most common and explicit form of participation is the election of and interaction with local politicians, whereas the form of participation in Type II models tends to be less evident. Considering these organizations have a specific purpose, they usually attract only actors interested in the subject. As a result, whereas Type I models have clear membership criteria (e.g., individuals living in a jurisdiction), the participation and representation criteria in Type II models are often more nuanced. When observing the constitution of Brazilian river basin committees, a complex effort to include representatives from different interested groups can be identified. Public sectors (municipal, state, and federal), civil society, and user representatives are mandatory. Nonetheless, the profile of civil society and user representatives changes drastically from one committee to another, as does the internal dynamics of each committee (ABERS; KECK, 2013).

Given that the civic participation and engagement of individuals are quite heterogeneous during the elections and in the interaction with politicians, the mere possibility of participation in new arenas and institutions does not automatically lead to effective participation (COHEN; DAVIDSON, 2011). Type II organizations, like committees, can be easily seized by specific organized interests, such as those of large companies or even of environmental groups that oppose the interests of users in increasing the water supply coverage
(BRANNSTROM, 2004). However, national government interests are usually more predominant in these instances (EMPINOTTI, 2011).

A second better-understood debate based on these typologies addresses the thematic scope and territorial scale under the responsibility of a jurisdiction. Type II governance models are specialized in one area to overcome the difficulty of Type I models in providing satisfactory coordination in contexts of multiple priorities. If we look beyond the issue of water resources, authorities or regional committees that manage public transport and solid waste collection or establish quality criteria for certain products are examples of Type II models that are more effective than traditional Type I models. However, specific issues managed by Type II organizations can easily prove to be complex, leading to pressures for expanding the scope of work of these organizations.

Conceptually, a gradual transformation of Type II models into reformed Type I versions is possible by redefining new geographical jurisdictions with the growth of their specific original purposes. As to the issue of water resources management, river basin committees could slowly increase their responsibilities to manage a series of policies that directly affect the availability and quality of water resources in an area. Topics such as sanitation, urban zoning, collection and processing of solid waste, economic development, environmental regulation, among many other related themes, could be easily included in the jurisdiction of a river basin committee. After all, everything is connected to water. As a result, the normative conceptual debate on water resources governance has started to think about the nexus among different sectors, instead of focusing on activities that affect water resources. According to Benson; Gain; Rouillard (2015), the argument in favor of the concept of nexus is to consider the management of resources and economic activities holistically to achieve systemic sustainability more easily.

In practical terms, however, this scenario usually leads to a new coordination problem, because the effectiveness of a Type II organization requires the commitment of Type I organizations. In other words, due to the huge legal and organizational barriers involving the expansion of the scope of work of a Type II organization dealing with complex issues, they need to coordinate their activities with Type I organizations, 
forming a cross-governance. The example of Brazilian river basin committees can be used once more. Even in committees that are working effectively, a vast number of issues that directly affect the water resources of a region are managed by states and municipalities. For instance, important issues such as urban zoning (especially in river banks), standards of construction, water supply, and sewage collection and treatment are under the responsibility of municipalities. As a result, Type II governance arrangements are often incorporated into Type I arrangements.

This responsibility for different areas, essential for a holistic approach to environmental issues, puts municipalities in a privileged position. In the current debate, municipalities are identified as one of the main potential innovation hubs for environmental policy and for facing the challenges posed by climate change (FUHR; HICKMAN; KERN, 2018). Besides that, municipalities are intersection points between Type I and
Type II governance models, acting as possible bridges between them (BETSILL; BULKELEY, 2004; ANDONOVA; HALE; ROGER, 2017). Nevertheless, this advantage is, at the same time, a disadvantage, since diverging priorities and pressures at the local level often create incentives to prevent the adoption of holistic strategies. Another typical disadvantage of municipalities is their financial and human resource limitations due to their subordinate political-administrative position in national States. In any case, the success of river basin committees - or any other Type II arrangement - in the sustainable management of water resources is, therefore, directly connected to the success of municipalities.

Hooghe and Marks (2003) emphasize that Type I and Type II governance are suitable for different issues, and coexist because they are complementary. A result is the variable number of independent and operationally differentiated Type II jurisdictions, alongside a more stable number of general Type I jurisdictions.

\section{DIVERSITY OF LOCAL ARRANGEMENT}

One of the greatest inventions that have enabled the development of modern science was the microscope, built by the Dutch merchant Anton van Leeuwenhoek, known as the father of microbiology, in the $17^{\text {th }}$ century. Studies based on his invention revealed to the world aspects of the physical and biological world until then belonging only to the realm of fantasy. If the previous section has helped us understand the tensions between Type I and Type II governance models and the central role of low-scale political-administrative units like municipalities, we must now adjust the focus of our analysis, just as with a microscope, to grasp better the dynamics inherent to this scale.

Analytically, we should bear in mind that municipalities can be regarded both as spaces/arenas for interaction between different actors, and as agents acting in governance systems.

This distinction becomes evident when considering the enormous socio-spatial heterogeneity existing in the universe of municipalities. In Brazil, for instance, when we speak of municipalities, both megalopolises such as São Paulo and its more than 12 million inhabitants, and the small Serra da Saudade in Minas Gerais State, with less than 800 residents, can be addressed. The scale and complexity of challenges faced in metropolises with millions of inhabitants are, doubtlessly, greater than those of smalland medium-sized cities. In large cities, historical patterns of urbanization and economic activity lead to different socio-spatial settings. Brazilian metropolises, in particular, have socioeconomic inequalities and processes of reconfiguration of the capitalist system that clearly shape the urban infrastructure, interacting with organizational capacities and patterns of relationship with the public sector, and directly affecting the priorities of residents from different regions of the same city (ROLNIK, 2015).

This internal heterogeneity of large cities represents a unique source of studies on local factors that affect the implementation of programs and public policies in both Type I and Type II governance contexts. The comparison between different sub-regions or neighborhoods of a large city allows an easier identification of the elements that influence the success or failure of policies or programs. A recent example of this potential is given by Silva-Sánchez and Jacobi (2016) in their analysis of satisfaction with linear parks, adopted as a strategy to recover urban rivers in São Paulo City. After evaluating data from interviews with municipal authorities and local community leaders involved in implementing the 16 linear parks in the city, the authors listed a series of factors that contributed to greater or lesser satisfaction with these new parks, such as local 
infrastructure, community organization, urban and environmental laws, competence of local administrators, among others. A limitation of the study, however, was not systematizing these differences to identify the conditions needed for a high level of satisfaction.

Although more evident, the heterogeneity of local dynamics is not exclusive to large municipalities. Smalland medium-sized municipalities, including those with more rural characteristics, are also marked by internal differences that affect the implementation of programs. For instance, Cooperman (2019) shows how even small municipalities in the inland of Ceará State present a huge diversity in water supply between rural communities only a few kilometers apart. According to the author, this difference reflects a historical pattern of local community organization, in which better-organized communities with stable leadership can coordinate their votes and elect politicians committed to the operation of the water supply system. Contrary to a purely clientelistic logic, the author reveals that organized communities often punish incompetent politicians by voting for other candidates. The perverse effect of this dynamic, however, is the persistence of precarious water supply conditions in less organized areas. This dynamic is not particular to Brazil. Carlitz (2017) investigated processes of decentralization of investments in water supply in Tanzania, and identified that communities with stronger organization and contacts with local politicians had better services.

Regarding municipalities as arenas allows a better perspective of potentials (and limitations) of civil society at the local level. As the studies mentioned above show, the organizational capacity of communities or neighborhoods is a determining factor for the success of policies and, consequently, of both Type I and Type II governance models. Understanding how this capacity is organized in each context is essential.

From the point of view of governance models, municipalities are also important actors, usually associated to their local administrations. Many of the governance systems classified by Hooghe and Marks (2003) as Type II are organized by municipal administrations. Recent studies show how global metropolises are leading transnational initiatives to combat climate change, or how large cities are coordinating metropolitan areas to provide public services of common interest. Administrations of smalland medium-sized cities are also potential catalysts of regional processes, such as planning water resources management of river basins crossing the borders of several municipalities (OLIVEIRA-ANDREOLI et al., 2019).

Data from the Organisation for Economic Co-operation and Development (OECD, 2015) indicate that the level of participation of municipalities in water resources collegial bodies depends on local conditions, the importance given to water issues, the motivation of mayors and collaborators, and the specific interests at stake. In general, this level of participation is considered low.

Thus, if on the one hand, understanding the central role and possible actions of municipal administrations in alternative Type II governance models is important, on the other hand, identifying the reasons for failures and inaction is equally relevant. Whereas the fragility of local civil society and the incompetence of municipal administrations are often indicated as reasons for the lack of effective public policies, numerous tasks under the responsibility of municipalities create practical difficulties for their implementation. The lack of trained staff and financial resources leads to a significant discrepancy between expectations and the ability to deliver results. In this regard, finding specific mechanisms that can facilitate or hinder the implementation of programs requires a systematic comparison between success and failure cases. If discussions on more comprehensive governance levels usually detect structural barriers to be addressed in the long term, local analyses produce precise diagnoses more easily and with greater potential for replication in other local contexts. Particularly in our case, Type II governance models can be considered options for the limited municipal participation in Type I models. The next section will illustrate this potential for water resources management.

\section{PATHS FOR LOCAL ACTION IN WATER RESOURCES MANAGEMENT: EXPERIENCES OF INTER-MUNICIPAL CONSORTIA AND RIVER BASIN COMMITTEES}

The formulation and implementation of water resources policies are, by nature, highly fragmented, and in- volve a multitude of interested parties and authorities from different levels of government and political ar- 
eas (OECD, 2015). Several governance arrangements, with varying degrees of local leadership, are possible in water resources management. According to Philippi Jr., Sobral and Carvalho (2019), governance is a mechanism of democratization and advancement of shared management, mitigating conflicts between the multiple users spread over the different geographical jurisdictions present in a river basin. For municipal administrations, governance arrangements different from the traditional hierarchy of Type I models also allow economies of scale in administrative and financial terms.
In this context, this section intends to present cases of different types of organizations with Type II governance that municipal administrations can use for water resources management: inter-municipal consortia and river basin committees. Both cases deal with organizational arrangements that attempt to make water resources management feasible, be it by focusing on the power of municipalities or by favoring several instances of local power and decision-making. These analyses can help us understand the difficulties and potentials of local governance in Brazil.

\section{Inter-municipal consortia for water resources management}

With the process of decentralization of public policies started with the redemocratization of the country, a known challenge in Brazilian cities lies in providing the numerous services under their responsibility. Especially in small- and medium-sized cities, the scarcity of financial and human resources created opportunities for the establishment of new forms of governance. A model designed to try alleviating these deficiencies was the inter-municipal consortium. Originally developed in the 1980s for the health sector, consortium is a type of formal cooperation between municipalities from the same region to provide a service (RIBEIRO; COSTA, 2000; CUNHA, 2014). In general, its function is to share the cost of services provided while generating financial and administrative resources for investments that could not be done by any participant alone. Thus, inter-municipal health consortia can be considered Type II organizations voluntarily coordinated by municipalities.

The relative success of this governance model can be seen in its dissemination beyond the provision of health services. Currently, inter-municipal consortia are established in the most diverse fields of activity, especially those related to environmental and water resources management. Sanitation and environmental licensing services are some of the thematic areas linked to the creation of consortia, and they show a huge growth potential (CARDOSO; CARVALHO, 2016). Recognizing the interrelation between these themes, we can observe a recent expansion in the scope of work of existing consortia or the construction of new multi-purpose ones, focused on the development of collective sustainable strategies. The process of creating these consortia also presented different catalysts. In some cases, they result from bottom-up dynamics, in which municipalities take initiative in the process, just like in the case of consortia in the north of Minas Gerais State; in others, state governments encourage the implementation of these organizations, just like in the case in Bahia State.

The National Water Agency (Agência Nacional das Águas - ANA, 2019c) highlights that the feasibility of shared options usually requires coordinated actions of greater technical, institutional, economic, and environmental complexity. Therefore, the public sector has a strategic role in the organization of these actions, and in the integrated analysis of the effects and benefits of interventions. However, as demonstrated previously, Type I governance models, such as municipal governments, have several kinds of limitations. In the case of inter-municipal consortia, the collective municipal management attempts to mitigate the issue of financial shortage. This fact emphasizes the need to rethink the federative pact, taking into account the multiple uses of water, since many public services of common interest, such as those related to environmental sanitation, are under municipal jurisdiction, as declared Philippi Jr., Sobral and Carvalho (2019).

Nonetheless, after analyzing data from the Survey of Basic Municipal Information (Pesquisa de Informações Básicas Municipais - MUNIC), conducted by the Brazilian Institute of Geography and Statistics (Instituto Brasileiro de Geografia e Estatística - IBGE) in 2017, we found that the percentage of Brazilian municipalities that participate in inter-municipal public consortia in areas related to water resources management is still relatively small (Table 2 ). Particularly with respect to sewage, the use of consortia is incipient, reflecting the general precarious situation of the country and the scarcity of financial resources for the infrastruc- 
Table 2 - Percentage of municipalities participating in public consortia according to the field of activity.

\begin{tabular}{|l|c|c|c|}
\hline & Water Supply (\%) & Sewage (\%) & Solid Waste Management (\%) \\
\hline Brazil & 12.8 & 8.3 & 11.1 \\
\hline North & 7.8 & 4.2 & 26.6 \\
\hline Northeast & 9.2 & 4.7 & 51 \\
\hline Alagoas State & 4.9 & 1.0 & 18.2 \\
\hline Bahia State & 12.7 & 8.6 & 41.8 \\
\hline Ceará State & 7.6 & 7.1 & 4.1 \\
\hline Maranhão State & 6.5 & 2.3 & 32.7 \\
\hline Paraíba State & 3.6 & 3.1 & 36.8 \\
\hline Pernambuco State & 21.1 & 8.1 & 1.8 \\
\hline Piauí State & 5.4 & 5.4 & 36 \\
\hline Rio Grande do Norte State & 9.0 & 4.2 & 76 \\
\hline Sergipe State & 6.7 & 1.3 & 20.4 \\
\hline Southeast & 13.6 & 11.2 & 22.1 \\
\hline South & 20.2 & 11.5 & 27 \\
\hline Midwest & 9.6 & 7.7 & 27 \\
\hline
\end{tabular}

ture projects needed. Inter-municipal consortia for solid waste management - an area directly related to the quality of water resources - have become more widespread. Although some of them are expanding their scope to include environmental management and urban planning themes, many seem to be limited to waste collection and landfill management. This scenario possibly results from the requirements provided in the National Solid Waste Policy, established by Federal Law No. 12.305/2010 (BRASIL, 2010).

When we assess the distribution of these consortia between states of the same region, such as the Northeastern, we can easily identify a great heterogeneity. Whereas states such as Maranhão and Piauí have practically no inter-municipal consortia, Pernambuco shows the highest percentage of municipalities with water supply consortia. In general, however, solid waste management is the main issue that mobilized these munic- ipalities due to the sharing of costs and infrastructure for collection and final disposal.

As shown by Hooghe and Marks (2003), Type II governance models, which match the profile of inter-municipal consortia, have among their characteristics a flexible design and the possibility of acting in specific jurisdictions with certain themes or activities. In this case, there can be a very fluid institutional arrangement to facilitate sanitation services, according to the interests and financial investment availability of the parties.

Interest in academic research on inter-municipal consortia is in solid development, mainly for the several decentralization efforts promoted in European countries in recent decades. A volume organized by Hulst and van Montfort (2007) analyzes various experiences of inter-municipal cooperation in European countries. The obvious difficulty in comparing these experienc- 
es lies in the different legal and institutional frameworks of each country, which directly shape the possible format of these local governance arrangements. Typical governance challenges, such as building effectiveness and legitimacy, are the most frequent diagnoses, especially in countries with weak traditions in autonomy and local cooperation (SILVA; TELES; FERREIRA, 2018). Nonetheless, analyses of waste collection and sewage treatment services carried out in European countries suggest that these inter-municipal cooperative arrangements are effective ways of improving coverage and reducing operational costs (SOUKOPOVÁ; VACEKOVÁ, 2018).

In Brazil, OECD data (2015) underline the performance of inter-municipal consortia for water resources management in Paraná State by means of "decentral- ized executive units" (unidades executivas descentralizadas - UEDs), which have executive power and responsibilities intrinsic to river basin agencies. Paraná shows an alternative governance model precisely because of the prominent role given to users and municipalities.

In Brazil, understanding the factors that contribute to the success (or lack thereof) and influence the performance of these arrangements is still limited. Whereas existing studies focus on metropolitan areas (MEZA et al., 2019), very little is known about inter-municipal consortia in small- and medium-sized cities. With the gradual increase in these governance models for the provision of services related to water resources, there is a huge research agenda to be developed.

\section{River basin committees for water resources management}

The establishment of the National Water Resources Policy in 1997 represented progress both in the conceptual sense and in the institutionalization of an integrated, participatory, and decentralized management, based on the integration among management bodies, users, and other institutions in river basin committees (SOBRAL et al., 2017). However, even though legislation addressed the space for expansion of social participation in IWRM, ANA data (2019b) indicate that the fulfillment of the Goal 6 target referring to the proportion of local administrative units with established policies and procedures aimed at local participation in water and sanitation management is not satisfactory in Brazil, because it corresponded to $49 \%$ in 2017 . This low percentage reflects the challenges and difficulties of the institutionalization of Type II governance models when made from top-down on a national scale. The mere creation of governance spaces does not automatically generate engagement, decision-making and organizational best practices of the actors involved. Just like Abers and Keck (2013) argue, the institutionalization of river basin committees has yielded very heterogeneous results, particularly regarding the participation of municipalities.

According to ANA (2011), river basin committees are collegial bodies formed by the public sector, representatives of users and civil society with regulatory, deliberative, and advisory power in the river basin of their jurisdiction. This context automatically leads to the creation of groups with distinct constitutions, practicing not only the interdisciplinarity but also the interinstitutionality of water resources management. River basin committee is a discussion forum that decides on issues related to water resources management of a specific river basin (ANA, 2019a). According to Philippi Jr., Sobral and Carvalho (2019), water resources management occurs at the federal level in river basins that cross state and national borders, and at the state level in river basins belonging to only one state. No specific institutional structure has been established at the municipal level; municipalities only have a representative role in river basins committees. This fact makes the activities of the committee and its representation even more relevant, because it is one of the only structures that guarantee municipal participation. Besides that, the committee structure allows the participation of bodies that are even more local, such as user associations, cooperatives, among others. This Type II governance model arrangement poses many challenges precisely because it places actors from different origins and interests in the same debate arena.

On the other hand, the more "local" role of the committee as an advisory and deliberative body is extremely complex, given the diverse interests and representation of its members. Until 2018, Brazil had 235 river basin committees - 10 federal committees (inter-state) and 225 state committees (Figure 1). 


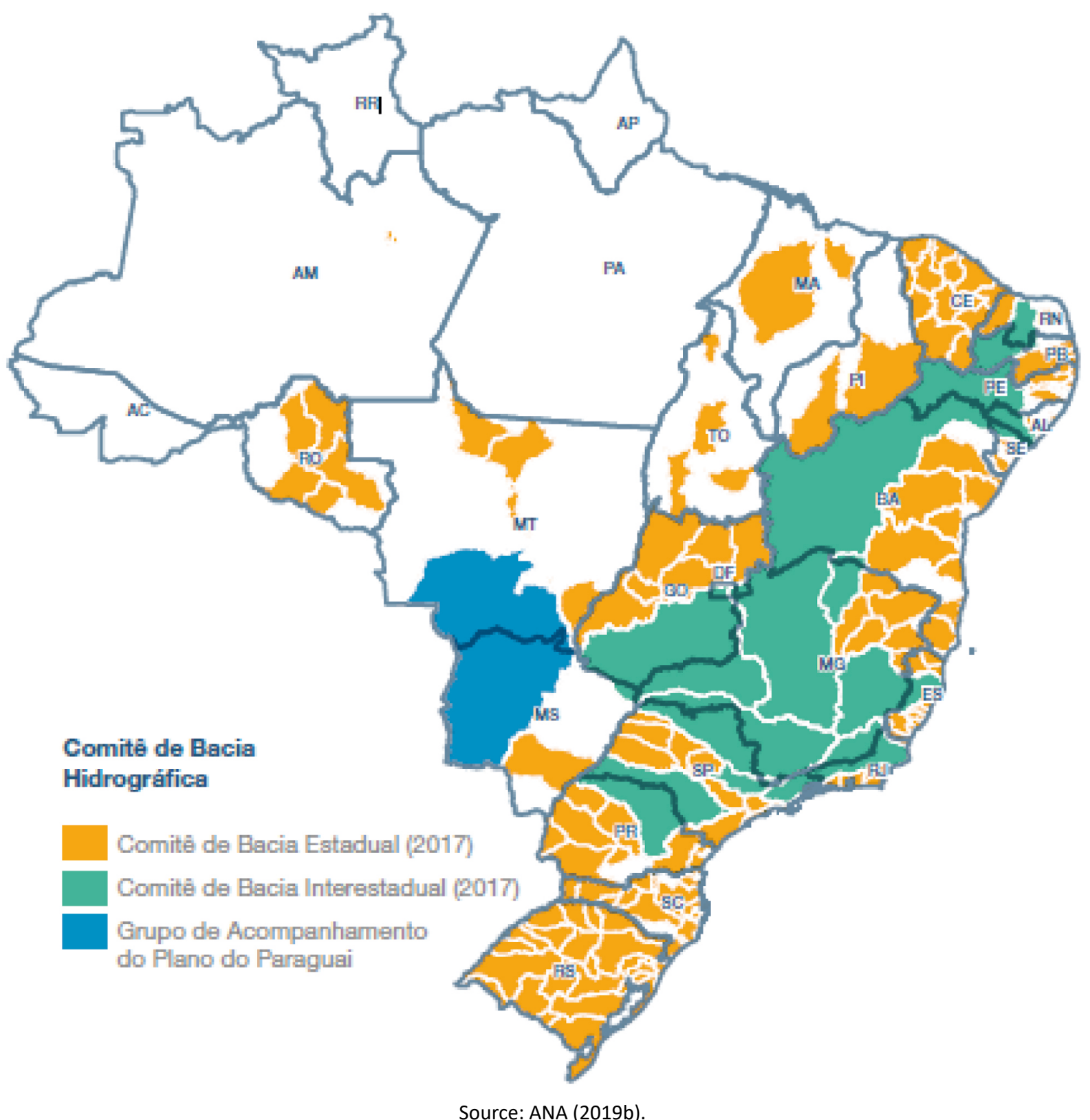

Figure 1 - River basin committees in Brazil.

Although late, the inherent difficulties of institutionalizing a complex Type II governance system, such as river basin committees, were recognized and inspired federal actions. In 2016, the National Program for Strengthening River Basin Committees (Programa Nacional de Fortalecimento dos Comitês de Bacias Hidrográficas - PROCOMITÊS) was created to support state com- mittees operationally and institutionally by providing financial aid for their operation (ANA, 2019a). This action aims to cover the lack of financial resources whose nature is usually voluntary in Type II organizations.

CBHSF illustrates governance with committees, with a significant role in semi-arid Brazil. 


\section{Experience of São Francisco River Basin Committee}

São Francisco river basin covers part of six states (Alagoas, Bahia, Goiás, Minas Gerais, Pernambuco, and Sergipe) and the Federal District, crosses 507 municipalities, and has a drainage area of $639,219 \mathrm{~km}^{2}$, which corresponds to $8 \%$ of the country's territory. Its main river - São Francisco - is 2,863 km long (CBHSF, 2019). Among its multiple uses, water supply for the population, irrigation, power generation, mining, fishing, and navigation are highlighted.

Created in 2001, the committee operates with 62 members, divided among users, who represent $38.7 \%$ of the total members; the public sector (federal, state, and municipal), 32.2\%; civil society, $25.8 \%$; and traditional communities, 3.3\% (CBHSF, 2019). The total number of members per representation is defined in the internal rules of CBHSF (CBHSF Deliberation No. 106/2019), as shown in the Figure 2.

National representatives correspond to the institutions:

- Ministry of the Environment;

- Ministry of Regional Development;

- Ministry of Economy;
- Ministry of Mines and Energy;

- National Indian Foundation.

The Federal District and each of the six states that compose the basin have a seat on the Committee. The distribution of municipal representatives is:

- three for Minas Gerais;

- two for Bahia;

- one for Pernambuco;

- one for Alagoas;

- one for Sergipe.

Users of water resources of the basin have 24 representatives:

- six for urban water supply;

- five for industry, collection, and dilution of industrial and mining effluents;

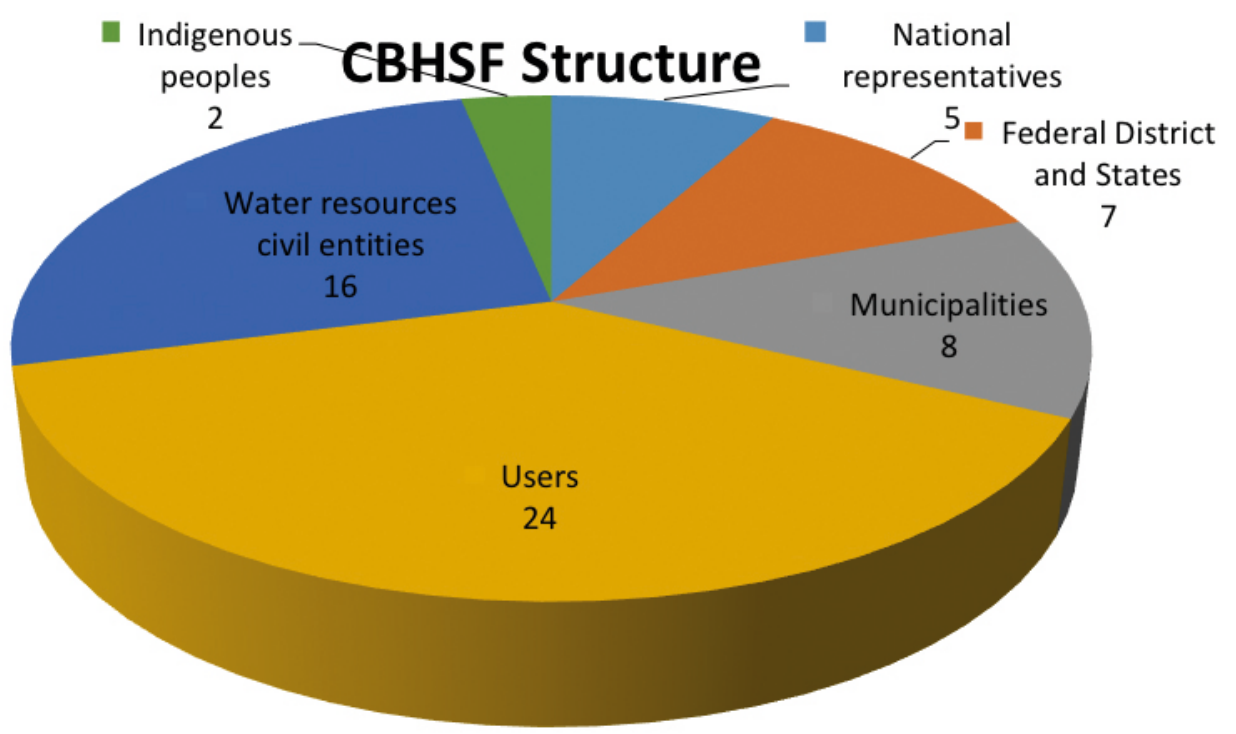

Source: adapted from the CBHSF Deliberation No. 106/2019 (CBHSF, 2019).

Figure 2 - Structure of São Francisco River Basin Committee. 
- six for irrigation and agriculture use;

- one for fluvial transport;

- four for fishing, tourism, and leisure activities;

- two for companies with concession or authorization to generate hydroelectric power.

The 16 representatives from water resources civil entities are:

- two for inter-municipal or user consortia and associations;

- five for technical organizations for education and research or other organizations;

- eight for non-governmental organizations;

- one for traditional quilombola communities (settlements with descendants of enslaved Africans), within the basin context.

The diversity of CBHSF participants is an attempt to ensure the balance in decisions and benefits to all areas, be it geographical or thematic. However, given the complexity and socio-environmental heterogeneity of the river basin, the committee's performance is often inefficient and does not meet the most urgent needs of the basin, favoring the wishes of groups of users. Rodorff et al. (2015) highlight that, despite the implementation of IWRM with the creation of a participatory committee, the challenging scenario for its establishment and operationalization is evident. In Brazil, legal framework and policy for water as a natural resource - primarily at the federal level, followed in greater detail by the state level - are implemented in municipalities, which have their own specificities, adopting the principle that water management and access to clean water are significant criteria at all levels. Bearing in mind that each of these levels has a web of interests of various multiusers, as well as the need to contemplate distinct social, economic, and institutional interests, according to a policy of social and economic growth, the challenge lies in providing transparency for each of these roles, and perceiving methods of strategic and tactical management.
This committee meets twice a year, besides the meetings of several technical chambers and four regional groups. Despite being a top-down participatory institution, the committee is a unique opportunity for the various interested parties to meet, exchange experiences, and build the foundations for a common understanding on water resources management (KÖPPEL; SIEGMUND-SCHULTZE, 2019).

The importance of tributary committees is also emphasized, which operate on an even more specific scale and can aid the committees of the broader geographical area to which they belong. In this perspective, research conducted by Souza Junior et al. (2017) on São Francisco river basin identified 44 water planning units for tributary rivers within the region of São Francisco, of which $26-$ a little over $59 \%$ of the existing units have no committee representation. The authors also underline the lack of guarantees that all implemented committees are representative and active.

Nonetheless, CBHSF recognized the central role of municipal administrations for a successful river basin management. In recent years, for instance, CBHSF funded the elaboration of sanitation plans in 63 of the $270 \mathrm{mu}$ nicipalities that comprise São Francisco river basin. In addition to providing information for municipal administrations to identify priority areas for action, the preparation of these plans is essential for municipalities to obtain federal resources for investing in water supply and a network for sewage collection. Thus, the interaction of a Type II organization with the structure of a Type I organization is clear, with municipalities as a common link.

Although considered a reasonably institutionalized committee with capacity for coordination, the studies cited above show the challenges that still exist for disseminating this governance model at the local level. An important reason for the difficulty in integrating municipalities in a more consistent way in these new multilevel governance structures is the predominance of interests of federal or state governments, often funders of local actions. Moreover, the lack of systematized knowledge about what makes some experiences and organizations successful and which of these elements can be replicated in other contexts are pointed out.

On the other hand, there is an understanding that the intense engagement of interested parties and the wide social mobilization must not overlap solid tech- 
nical knowledge and the exercise of public authority. The need to complement or even integrate bottom-up approaches with a top-down process to ensure the fulfillment of national targets and long-term goals is also known (OECD, 2015).

Empinotti (2011) emphasizes that participatory institutions require commitment and time to negotiate, besides mastering the technical language that prevails in this area. Even with dedication and effort in participating in discussions and arguments, many variables can neutralize the entire negotiation. In this regard, Ostrom (2011) declares the need for valuing the knowledge about realities of local governance structures and the trust among decision-makers, highlighting that these two attributes related to individual decisions are not often included in current analyses.

\section{CONCLUSION}

The present article aimed to present a brief and non-exhaustive summary of the current debate about water resources governance, stressing the importance given to the local level by the international literature. As argued, Brazil is no exception. Most challenges faced by water resources governance in Brazil require some level of action from municipal governments. Nonetheless, given that municipalities are multi-purpose districts, they need to split their scarce human and financial resources between other demands beyond the water issue. The main challenge for the new forms of governance created for water resources management is consistently engaging these local actors.

The role of the local level in water resources management, presented as committees and inter-municipal consortia - examples of Type II governance arrangements - , reveals the expansion of local representative action in the decision-making process. In consortia, municipalities are protagonists and collectively define their priorities. On the other hand, municipalities need a more effective way of increasing their participatory space in river basin committees. At the same time, in these spaces, the local level can have other representations. These participatory spaces demand greater governmental support to ensure their full operation and autonomy of action. In addition, the functioning of these bodies requires ongoing training for participants, as well as financial support.

The review of official and national literature data shows that municipalities do not ignore the need to adopt new management models in response to their known financial and technical limitations. Type II governance structures, such as inter-municipal consortia and river basin committees, are considered opportunities to meet these needs due to their flexibility, multilevel scale, and polycentric nature. However, the scarcity of knowledge of which factors and strategies can lead to the successful organization of local participation and cooperation in these new governance arrangements is evident. Identifying which factors are behind the success of inter-municipal consortia or better planning of water resource management by local governments is of utmost importance for the development of actions and programs that can encourage the replication of these effective cases. One way of overcoming criticism related to the lack of political will from municipal authorities is knowing the reasons for successful cases.

Engagement of municipal leaders is obviously crucial. So are financial resources. International literature shows that these two elements walk together. The availability of resources is a beacon for local authorities and a clear incentive for their engagement. However, as Termeer, Dewulf and Biesbroek (2017) state, an important element for the success of cases of adaptive changes related to climate change is the establishment of feasible and achievable goals, and action plans within a relatively short period. Namely, the elaboration of small projects, so municipal authorities can see concrete results faster, is an effective way of building trust and foundations for larger-scale projects.

Another aspect highlighted by the authors is the usual tendency of central authorities to dirigisme, resulting in an underestimation of local actors. Top-down processes, typical of Type I governance models, are also likely to occur in Type II models. Thus, river basin committees dominated by groups insensitive to the challenges experienced by local governments and their possible contributions to finding alternative solutions weaken the legitimacy and transformative potential of new governance models. In addition to institutional spaces, the communication between parties must be perceived as an effective dialog, rather than a monologue. 
The recent Brazilian academic production is particularly valuable in identifying and describing the processes of institutionalization of new forms of water resources governance. Systematic comparisons focused on local experiences, such as tributary basin committees, are a still unexplored and rich source of knowledge. Further research in this field should consider that interdisciplinary analysis is essential. Attempting to broaden the theoretical and analytical concept to understand how local organizations work and change is a necessary step to improve water resources governance.

\section{REFERENCES}

ABERS, R. N.; KECK, M. E. Practical Authority: Agency and institutional change in Brazilian water politics. Oxford: Oxford University Press, 2013.

AGÊNCIA NACIONAL DE ÁGUAS (ANA). Conjuntura dos recursos hídricos no Brasil 2019: informe anual. Brasília: ANA, 2019a.

AGÊNCIA NACIONAL DE ÁGUAS (ANA). O comitê de bacia hidrográfica: o que é e o que faz? Brasília: Agência Nacional de Águas, 2011. (Cadernos de Capacitação em Recursos Hídricos, 1.)

AGÊNCIA NACIONAL DE ÁGUAS (ANA). ODS 6 no Brasil: visão da ANA sobre os indicadores. Brasília: ANA, 2019b.

AGÊNCIA NACIONAL DE ÁGUAS (ANA). Plano Nacional de Segurança Hídrica. Brasília: ANA, 2019c.

ANDONOVA, L. B.; HALE, T.; ROGER, C. B. National policy and transnational governance of climate change: Substitutes or complements? International Studies Quarterly, v. 61, n. 2, p. 253-268, 2017. https://doi.org/10.1093/isq/sqx014

ANSELL, C.; TORFING, J. Handbook on Theories of Governance. Cheltenham: Edward Elgar Publishing, 2016.

BENSON, D.; GAIN, A. K.; ROUILLARD, J. J. Water governance in a comparative perspective: From IWRM to a 'nexus' approach? Water Alternatives, v. 8, n. 1, p. 756-773, 2015.

BETSILL, M. M.; BULKELEY, H. Transnational networks and global environmental governance: The cities for climate protection program. International Studies Quarterly, v. 48, n. 2, p. 471-493, 2004. https://doi.org/10.1111/j.00208833.2004.00310.x

BRANNSTROM, C. Decentralising water resource management in Brazil. European Journal of Development Research, v. 16, n. 1, p. 214-234, 2004. https://doi.org/10.1080/09578810410001688815

BRASIL. Lei no 12.305, de 2 de agosto de 2010. Institui a Política Nacional de Resíduos Sólidos e dá outras providências. Brasil, 2010. Disponível em: <https://www.planalto.gov.br/ccivil_03/_ato2007-2010/2010/lei/l12305.htm>. Acesso em: fev. 2020.

CARDOSO, L. L.; CARVALHO, A. A. E. S. Desafios para os municípios da região metropolitana de Salvador, Bahia, frente à descentralização do licenciamento ambiental. Revista Brasileira de Ciências Ambientais, n. 40, p. 57-68, 2016. https:// doi.org/10.5327/Z2176-9478201613314

CARLITZ, R. D. Money flows, water trickles: Understanding patterns of decentralized water provision in Tanzania. World Development, v. 93(C), p. 16-30, 2017. https://doi.org/10.1016/j.worlddev.2016.11.019

COHEN, A.; DAVIDSON, S. The watershed approach: Challenges, antecedents, and the transition from technical tool to governance unit. Water Alternatives, v. 4, n. 1, p. 1-14, 2011.

COMITÊ DE BACIA HIDROGRÁFICA DO RIO SÃO FRANCISCO (CBHSF). A bacia. Available from: <http://cbhsaofrancisco. org.br/a-bacia/>. Accessed on: Jan. 2019. 
CONCA, K. Governing water: Contentious transnational politics and global institution building. Cambridge: Massachusetts Institute of Technology, 2006.

COOPERMAN, A. D. Trading favors: Local politics and development in Brazil. Thesis (Doctoring on Politics Science) Columbia University, New York, 2019.

CUNHA, R. E. Federalismo e relações intergovernamentais: Os consórcios públicos como instrumentos de cooperação federativa. Revista do Serviço Público, v. 55, n. 3, p. 5-36, 2014. https://doi.org/10.21874/rsp.v55i3.249

EMPINOTTI, V. L. E se eu não quiser participar? O caso da não participação nas eleições do comitê de bacia do Rio São Francisco. Ambiente \& Sociedade, v. 14, n. 1, p. 195-211, 2011. https://doi.org/10.1590/S1414-753X2011000100011

FUHR, H.; HICKMAN, T.; KERN, K. The role of cities in multi-level climate governance: local climate policies and the $1.5 \mathrm{C}$ target. Current Opinion in Environmental Sustainability, v. 30, p. 1-6, 2018. https://doi.org/10.1016/j.cosust.2017.10.006

HOOGHE, L.; MARKS, G. Unraveling the central state, but how? Types of multi-level governance. American Political Science Review, v. 97, n. 2, p. 233-243, 2003. https://doi.org/10.1017/S0003055403000649

HULST, R.; VAN MONFORT, A. Inter-Municipal Cooperation in Europe. Dordrecht: Springer, 2007.

JACOBI, P. R.; SPÍNOLA, A. L. G. Aspectos institucionais e conceituais da governança da água: intrdumentos, inovações e desafios. In: PHILIPPI JR., A.; SOBRAL, M. C. M. (eds.). Gestão de bacias hidrográficas e sustentabilidade. Barueri: Manole, 2019.

KÖPPEL, J.; SIEGMUND-SCHULTZE, M. Diversas arenas da governança das bacias hidrográficas. In: PHILIPPI JR., A.; SOBRAL, M. C. M. (eds.). Gestão de bacias hidrográficas e sustentabilidade. Barueri: Manole, 2019.

LE GALÈS, P. À chaque ville sa gouvernance. Auxerre: Sciences Humaines, 2004. (Hors-série, n. 44.)

MANCILLA-GARCÍA, M.; HILLEMAN, J.; BODIN, Ö.; NILSSON, A.; JACOBI, P. R. The unique role of municipalities in integrated watershed governance arrangements: A new research frontier. Ecology and Society, v. 24, n. 1, p. $28,2019$. https://doi.org/10.5751/ES-10793-240128

MEZA, O. D.; GRIN, E. J.; FERNANDES, A. S.; ABRUCIO, F. L. Intermunicipal cooperation in metropolitan regions in Brazil and Mexico: Does Federalism matter? Urban Affairs Review, v. 55, n. 3, p. 887-922, 2019. https://doi. org/10.1177\%2F1078087418816433

OLIVEIRA-ANDREOLI, E. Z.; SILVA, F. L.; LÓPEZ, F. M. A.; MACHADO, R.; TEODORO, C. C.; BIANCHINI JR., I.; CUNHASANTINO, M. B.; FUSHITA, A. T.; CRESTANA, S. Importância do planejamento regional para a manutenção dos usos múltiplos da água em bacias hidrográficas. Revista Brasileira de Ciências Ambientais, n. 52, p. 16-27, 2019. http:// dx.doi.org/10.5327/Z2176-947820190479

ORGANISATION FOR ECONOMIC CO-OPERATION AND DEVELOPMENT (OECD). Governança dos Recursos Hídricos no Brasil. Paris: OECD Publishing, 2015. http://dx.doi.org/10.1787/9789264238169-pt

OSTROM, E. Reflections on "Some Unsettled Problems of Irrigation". The American Economic Review, v. 101, n. 1, p. 49-63, 2011. http://dx.doi.org/10.1257/aer.101.1.49

PHILIPPI JR., A.; SOBRAL, M. C. M; CARVALHO, R. M. C. M. O. Bacia hidrográfica no contexto da sustentabilidade. In: PHILIPPI JR., A.; SOBRAL, M. C. M. (eds.). Gestão de bacias hidrográficas e sustentabilidade. Barueri: Manole, 2019. p. 3-18.

RIBEIRO, J. M.; COSTA, N. R. Regionalização da assistência à saúde no Brasil: Os consórcios municipais no Sistema Único de Saúde (SUS). Planejamento e Políticas Públicas, n. 22, p. 173-220, 2000. 
RODORFF, V.; SIEGMUND-SCHULTZE, M.; KÖPPEL, J.; GOMES, E. T. A. Governança da bacia hidrográfica do Rio São Francisco: Desafios de escala sob olhares inter e transdisciplinares. Revista Brasileira de Ciências Ambientais, n. 36, p. 19-44, jun. 2015. https://doi.org/10.5327/Z2176-947820151003

ROLNIK, R. Guerra dos lugares: a colonização da terra e da moradia na era das finanças. São Paulo: Boitempo, 2015.

SHARMA-WALLACE, L.; VELARDE, S. J.; WREFORD, A. Adaptive governance good practice: Show me the evidence! Journal of Environmental Management, v. 222, p. 174-184, 2018. https://doi.org/10.1016/j.jenvman.2018.05.067

SILVA, P.; TELES, F.; FERREIRA, J. Intermunicipal cooperation: The quest for governance capacity? International Review of Administrative Sciences, v. 84, n. 4, p. 619-638, 2018. https://doi.org/10.1177\%2F0020852317740411

SILVA-SÁNCHEZ, S.; JACOBI, P. R. Implementation of riverside parks in the city of São Paulo - Progress and constraints. Local Environment, v. 21, n. 1, p. 65-84, 2016. https://doi.org/10.1080/13549839.2014.922060

SOBRAL, M. C. M.; MONTENEgRO, S. M. G.; CARVALHO, R. M. C. M. O.; MELO, M. G. S. Institucionalidade da interdisciplinaridade na gestão de recursos hídricos no Brasil. In: PHILIPPI JR., A.; FERNANDES, V.; PACHECO, R. C. S. Ensino, Pesquisa e inovação: desenvolvendo a interdisciplinaridade. Barueri: Manole, 2017. p. 463-493.

SOUKOPOVÁ, J.; VACEKOVÁ, G. Internal factors of intermunicipal cooperation: what matters most and why? Local Government Studies, v. 44, n. 1, p. 105-126, 2018. https://doi.org/10.1080/03003930.2017.1395739

SOUZA JUNIOR, C. B.; SIEGMUND-SCHULTZE, M.; KÖPPEL, J.; SOBRAL, M. C. Sinais de um problema crônico: a governança hídrica carece promover os comitês de bacias, coordenar planos e gerir informações. Revista Ambiente e Água, v. 12, n. 6, p. 1054-1067, 2017. https://doi.org/10.4136/ambi-agua. 2044

TERMEER, C. J. A. M.; DEWULF, A.; BIESBROEK, R. Transformational change: Governance internventions for climate change adaptation from a continuous change perspective. Journal of Environmental Planning and Management, v. 60, n. 4, p. 558-576, 2017. https://doi.org/10.1080/09640568.2016.1168288

UNITED NATIONS ORGANIZATION (UN). Transformando nosso mundo: a Agenda 2030 para o desenvolvimento sustentável. New York: ONU, 2015. Available at: <https://nacoesunidas.org/pos2015/ods6/>. Accessed on: Jan., 2010.

WHALEY, L.; CLEAVER, F. Can "functionality" save the community management model of rural water supply? Water Resources and Rural Development, v. 9, p. 56-66, 2017. https://doi.org/10.1016/j.wrr.2017.04.001

WOODHOUSE, P.; MULLER, M. Water governance: an historical perspective on current debates. World Development, v. 92, p. 225-241, 2017. https://doi.org/10.1016/j.worlddev.2016.11.014 